\title{
Measuring Early-Primary Students Resilience through Playful Learning
}

\author{
Fadhli Muhibuddin ${ }^{1}$, Purnomo Rochmat Aldy ${ }^{2}$, Deka Dyah Utami ${ }^{3}$, Rizal Arifin ${ }^{4}$, Sylvester \\ Arnab $^{5}$, Katherine Wimpenny ${ }^{6}$, Tomlins Richard ${ }^{7}$ \\ \{purnomo@umpo.ac.id ${ }^{2}$ \} \\ Universitas Muhammadiyah Ponorogo, Ponorogo, Indonesia $1,2,3,4$ \\ Coventry University, Coventry, United Kingdom ${ }^{5,6,7}$
}

\begin{abstract}
The Indonesian government has established a policy that the learning process for all levels of education continues during the COVID 19 pandemic with an online or digital system, meaning that students carry out learning activities at home digitally. The problem that arises is the level of social resilience of students in learning during the COVID-19 period in Indonesia, which indicates that the COVID-19 pandemic still exists. This study aimed to analyze the level of social resilience of students in early education and basic education during the COVID-19 pandemic and how social structures affect the level of resilience. The research methods used were qualitative and quantitative approaches. A survey was conducted on 115 respondents. Students' resilience was measured by the NMRQ Questionnaire (Nicholson McBride Resilience Questionnaire) and the factors affecting resistance were measured by the SAJA Questionnaire. From the qualitative approach, the study found that the level of social resilience of students was quite high due to the application of the ACES-based environmental and fun learning model using lego, makey-makey, masks, and music. From the quantitative approach, most students could build resilience and change their perceptions from difficult conditions to pleasant learning conditions due to social and economic factors. The factor that most influences the level of social resilience of primary school early childhood was the family socioeconomic factor.
\end{abstract}

Keywords: Social resilience; early primary school students; NMRQ method; ACES

\section{Introduction}

Indonesian Education Minister, Nadiem Makarim, stated that there had not been any discussions and solutions that were truly effective globally to resolve the education crisis that occurred as a result of the policy of closing all schools to prevent the corona virus. Not only in Indonesia, almost 50 other countries have implemented similar policies and changed the learning system into online learning. At least distance learning is one solution that can be done, although initially it will be responded negatively to achieve educational outcomes and quality [1].

One of the strategies of the Indonesian Government in suppressing the spread of Covid-19 is to establish a Large-Scale Social Restriction (PSBB) policy [2] to prevent the spread of the COVID-19 pandemic nationally. The PSBB policy is regulated in Government Regulation Number 21 of 2020 which was enacted on March 31, 2020 [3]. As an archipelago country, many constraints have been reported due to the PSBB policy, such as geographic challenges and challenges related to infrastructure. For example, the lack of even internet access in the 
outermost, underdeveloped and marginalized areas, the lack of readiness of students and teachers for online learning, and other technical obstacles that require access to cities.

Children in Indonesia have become "victims" of government policies in terms of meeting their learning needs. Until 1 April 2020, UNESCO recorded that at least 1.5 billion school-age children were affected by Covid 19 in 188 countries, including 60 million in Indonesia [4]. But we must understand that above all interests, health factors must be the main reason to survive and rise from this pandemic.

The Indonesian news head office stated that the Indonesian education ministry has moved quickly by making a policy of broadcasting subject matter on national TV, internet data assistance for academics, developing android-based distance learning applications such as Learning Resources, Digital Classroom, Virtual Laboratory, Quizizz which are all accessible by teachers, parents and students to learn from home [5]. Some children study at home with assistance from their parents, but some parents have not been able to accompany them to study independently because of their business. The question that arises, "Are children ready to learn without assistance?" and "Are parents ready to accompany the learning process?" As we all know, the age of children is the age that really needs assistance and supervision from their closest people. The resilience of children in this phase is questioned, "Is it true that at an early age child already have a good level of resilience?"

Resilience is one's ability to remain steadfast even in difficult circumstances [6]. The level of resilience of children when affected by a disaster, depends on their adjustment to the system, both the system of children's relationships with their nanny, family, and friends. As well as the resources that they can get from their family, environment and school [7]. Resilience in learning during the pandemic is expected to be formed by the majority of early childhood. This is because resilience is very influential in maintaining the enthusiasm and motivation of children's learning so that they are not left behind in studying learning materials and can maintain the quality of education of Indonesian children [8].

\section{Literature Review}

As an effort to develop children's resilience, this study applied several playful learning methods such as making masks from used materials, makey-makey, and learning while playing music. The concept of play in Playful learning is the key to expanding and developing children's learning experiences with the surrounding environment, developing learning autonomy and children's learning freedom. By playing, children can explore gradually, repeatedly, and continuously on understanding and interpretation of various concepts [9].

To measure the level of children's resilience, three indicators can be used as reference, namely absorptive related to the stability of the child's situation, adaptive related to the flexibility of the child's situation and transformational capacity related to the child's situation which requires a structural change [10].

Early-primary students are children who are formally at the kindergarten and elementary school levels. Early children are in the age range of 5 to 6 years, while primary children are in the age range of 6 to 13 years. According to Piaget, early children are still at the level of preoperational thinking and primary children are at the level of operational concrete thinking, both of which are the ability to think on basic concrete concepts [11].

The ACES project (https://aces.gchangers.org/) aims to investigate transformative education towards the development of social resilience in young people in primary and 
secondary education through the lens and practice of fun learning. It particularly studies the impact of the pedagogical model on Sustainable Development Goals (SDGs) or sustainable development in the fields of poverty, welfare and health, quality of education and gender equality in Indonesia, England, Malaysia and Vietnam. Therefore, this article investigated resilience and the factors that could impact young people in their learning. The study used qualitative and quantitative approaches for measuring resilience and explores how social structures affect the level of resilience.

\section{Method}

This study used qualitative and quantitative approaches. The instrument used to measure the level of children's resilience was adapting the Nicholson McBride Resilience Questionnaire (NMRQ) questionnaire which has 12 questions and a minimum score of 0 and a maximum of 60 with a score of: 0-37 "developing"; 38-43 "established"; 44-48 "strong"; and 49-60 "exceptional". The use of the NMRQ instrument was based on considerations to analyze the level of resilience of children during the Covid-19 pandemic.

The sampling technique used in this study was purposive sampling, in which the sample was selected according to the criteria determined by the researchers. The inclusion criteria of the participants were all registered early childhood and basic education students who were actively participating in learning at formal education institutions in Ponorogo Regency, and were willing to become respondents by filling in a letter of approval given and guided by the ACES Indonesia Ambassador. The number of students who took part in this study was 115 participants.

Furthermore, the instrument for measuring the factors that affect children's resilience was the SAJA questionnaire (2018) with indicators to measure social structure, consisting of social and economic status, health status, educational level, and living conditions at home. SAJA instrument has 9 questions on a 1-10 Likert scale with details include 1-3: Never, 4-6: Rarely, 7-8: Sometimes, 9-10: Always [18]. To identify the correlation of resilience and social structure, ordinary least square and causality analysis were used because it uses the ordinal data type [18]. Researchers have asked for consent from parents and participants with a total of 115 participants before data collection. In addition, the researcher has also conveyed the research objectives to the respondents, then calculates and processes the data using STATA.

$$
N M R Q=\alpha+\beta_{1} S E S_{1}+\beta_{2} H S_{2}+\beta_{3} E L_{3}+\beta_{4} L H O_{4}+e
$$

$\begin{array}{ll}\text { SES } & : \text { Social economy status } \\ \text { HS } & : \text { Health Status } \\ \text { EL } & : \text { Education Level } \\ \text { LHO } & : \text { Land and home ownership }\end{array}$

\section{Results and Discussion}

Findings regarding students in early childhood education (3-6 years) show higher resilience in the developed and established categories compared to students in primary education. These 
findings echo Piaget's theory which states that early school children are in the age range for personality formation. Children become happier individuals when forming groups (with friends, relatives, and parents) and when exploring their environment [11]. Preschoolers mostly define themselves in terms of activities and physical abilities such as "I can run fast, I can climb stairs, I can draw flowers". This reflects their sense of initiative to carry out an activity, and children's need for independence when facing new lessons [12]. The home environment is a learning center for children because when they are in the home environment the children's learning attitude is first formed [13]. Thus, it can be concluded that early childhood has higher learning resilience during the pandemic than elementary school children because of their simple (pre-operational) thinking patterns. Their group learning needs have been met with the participation of family members at home during the pandemic.

Primary school students (6-8 years) show higher resilience at strong levels; similar to the OECD 2018 findings which stated that $89 \%$ of students agree or strongly agree that they can usually find a way out of difficult situations (OECD average: $84 \%$ ), and $59 \%$ agree or strongly agree that, when they fail, they are worried about what others think of them (OECD average: $56 \%$ of students). This is also because activities at home are more open and freer compared to activities in preschool. Primary schools are more defined and regulated in a formal sense.

Students in primary school also show higher resilience in the exceptional grade category when compared to early school. It has been reported that students in Indonesia are among the most cooperative, compared to other PISA participating countries and economies ((PISA Index 0.34 , rank $7 / 77,2018)$ [14]. Around $91 \%$ of students in Indonesia report sometimes or always happy.

In short, all students (early primary school students) have strong social resilience scores. Social resilience (strong level) means that children are able to learn in a stable (absorptive) and flexible (adaptive) during a pandemic period with changes in the learning system that are far different from before (transformational capacity). This is influenced by the implementation of playful learning in learning which is able to attract attention to learning and build early-primary students' intrinsic and extrinsic learning motivation during the pandemic so that it has a positive impact on the development of children's social resilience. This finding is supported by Prensky's theory which states that early childhood learning retention which is classified as digital native can be increased by using learning activities that attract their attention such as by implementing game-based learning supported by social interaction of all family members [16]. • It was also previously reported that in Indonesia, 70\% of students (OECD average: 67\%) reported that the majority of students were satisfied with their life (students reporting between 7 and 10 on a 10point life satisfaction scale) [15].

Early primary school students' self-actualization needs (surviving a pandemic) can be met if their basic needs are met, namely physical needs, security needs, love and feeling needs, and self-esteem needs. During the pandemic, when all students study at home, this need has been met in their individual homes [17]. Therefore, the strong level of resilience can be achieved because all students can actualize themselves more optimally when studying at home. Figure 1 shows the Maslow Hirarcial Needs Theory. 


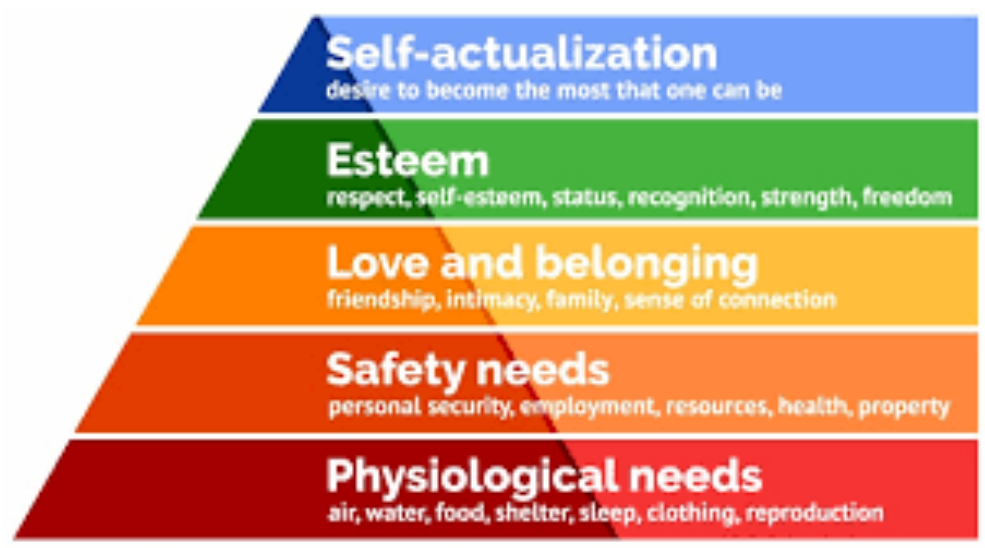

Fig. 2. Maslow Hirarcial Needs Theory.

Table 1 shows the NMRQ Modelling Result.

Table 1. NMRQ Modelling Results

Dependent Variable: NMRQ

Method: Least Squares

Date: 11/06/20 Time: 14:06

Sample: 1115

Included observations: 115

\begin{tabular}{crccr}
\hline \multicolumn{1}{c}{ Variable } & Coefficient & Std. Error & t-Statistic & Prob. \\
\hline & & & \\
C & 9.659854 & 3.047338 & 3.169932 & 0.0020 \\
SES & 3.278110 & 0.574314 & 5.707869 & 0.0000 \\
HS & 3.202355 & 0.366244 & 8.743768 & 0.0000 \\
EL & 2.630960 & 0.730700 & 3.600602 & 0.0005 \\
LHO & 2.405162 & 0.548530 & 4.384745 & 0.0000 \\
& & & & \\
R-squared & & & \\
Adjusted R-squared & 0.652932 & Mean dependent var & & \\
S.E. of regression & 0.640311 & S.D. dependent var & & 5.194003 \\
Sum squared resid & 3.714796 & Akaike info criterion & & 5.505029 \\
Log likelihood & 1517.968 & Schwarz criterion & & 5.624374 \\
F-statistic & -311.5392 & Hannan-Quinn criter. & & 2.063353 \\
Prob(F-statistic) & 51.73512 & Durbin-Watson stat & \\
\hline
\end{tabular}


The factor that most influences children's resilience is the socioeconomic status of their parents. Socioeconomic status and NMRQ have a positive relationship with a probability value of 0.0000 or $0 \%$, which means that socioeconomic status affects NMRQ. With the coefficient value owned by the socioeconomic status of 3.287110, it means that if the SES increases by 1 level, the NMRQ increases by 3.278110. On the other hand, if the socioeconomic status decreases by 1 level, then NMRQ will decrease by 3.278110. In Maslow's theory of needs, socio-economic is at the level of primary needs on physical needs. When these basic needs have been met, the children's self-actualization in learning will be achieved and will have an impact on their strong level of resilience when learning during a pandemic and vice versa.

\section{Conclusion}

Strong levels showed that most early and primary students were able to build resilience and changed their perceptions from difficult conditions to acceptable learning conditions. The most influential factor for developing a strong level of resilience is socioeconomic status. The results of this preliminary study are used to create a conducive learning environment to strengthen the social resilience of students in several Kindergarten and Primary School communities in Indonesia.

\section{Acknowledgement}

Thank you for UKRI-GCRF and Economic and Social Research Council funding and ACES Ambassador Indonesia to get the data as well. The authors also express gratitude to all teams from Coventry University, Universiti Malaysia Sarawak, and Hanoi University of Science and Technology, also technicians who help prepare equipment set-ups our presentations.

\section{References}

[1] Y. Lee, "The pandemic's effect on education is not being discussed enough, says Indonesian minister," CNBC, Singapore, Sep. 2020.

[2] Kemenkopmk, "Pembatasan Sosial Berskala Besar," Kementerian Koordinator Bidang Pembangunan Manusia dan Kebudayaan Republik Indonesia, 2020. https://www.kemenkopmk.go.id/pembatasansosial-berskala-besar (accessed Dec. 13, 2020).

[3] Kemenlu, "KEBIJAKAN PEMERINTAH REPUBLIK INDONESIA TERKAIT WABAH COVID19," Kedutaan Besar Republik Indonesia di Brussels, Belgia, 2020. https://kemlu.go.id/brussels/id/news/6349/kebijakan-pemerintah-republik-indonesia-terkait-wabahcovid-19 (accessed Dec. 13, 2020).

[4] P. Web, "Pembelajaran Online di Tengah Pandemi Covid-19, Tantangan yang Mendewasakan," Pusat Data dan Teknologi Informasi Kementerian Pendidikan dan Kebudayaan Republik Indonesia, 2020. https://pusdatin.kemdikbud.go.id/pembelajaran-online-di-tengah-pandemi-covid-19-tantanganyang-mendewasakan/ (accessed Dec. 13, 2020). 
[5] Indriani, "Belajar dari rumah, kewalahan orang tua hingga kesiapan guru," Antaranews, 2020. https://www.antaranews.com/berita/1363634/belajar-dari-rumah-kewalahan-orang-tua-hinggakesiapan-guru (accessed Dec. 13, 2020).

[6] K. Reivich and A. Shatté, The resilience factor: 7 essential skills for overcoming life's inevitable obstacles. Broadway books, 2002.

[7] A. S. Masten and A. J. Barnes, "Resilience in children: Developmental perspectives," Children, vol. 5, no. 7, p. 98, 2018.

[8] A. Emda, "Kedudukan motivasi belajar siswa dalam pembelajaran," Lantanida J., vol. 5, no. 2, pp. 172-182, 2018.

[9] S. Arnab, Playful and Gameful Learning in a Hybrid Space, vol. 176. 2017.

[10] [H. Jeans, G. E. Castillo, and S. Thomas, "Absorb, adapt, transform: Resilience capacities," Oxfam, 2017.

[11] J. Piaget, "The theory of stages in cognitive development." in Measurement and Piaget., New York, NY, US: McGraw-Hill, 1971, pp. ix, 283-ix, 283.

[12] E. . Erikson, Childhood and Society. New York: Norton, 1950.

[13] C. Gordon, R. Turner, T. Cottle, and K. Ger-, "Systemic Senses of Self *," Sociol. Inq., vol. 38, 1967.

[14] OECD, "Indonesia Student performance (PISA 2018)," "Education GPS," 2018.

[15] F. Avvisati M.Schwabe, "Indonesia What 15-year-old students in Indonesia know and can do Figure 1. Snapshot of performance in reading, mathematics and science," vol. I-III. pp. 1-10, 2018.

[16] P. Marc, "Digital Natives, Digital Immigrants Part 1," Horiz., vol. 9, no. 5, pp. 1-6, Jan. 2001, doi: $10.1108 / 10748120110424816$.

[17] A. H. Maslow, “A theory of human motivation.," Psychol. Rev., vol. 50, no. 4, pp. 370-396, 1943, doi: $10.1037 / \mathrm{h} 0054346$.

[18] Creswell. Jhon, 2016, Research Design : Qualitative, Quantitative, Mixed Methods approaches, SAGE Publications. 